Imágenes en Urología

\title{
Neumonitis post-instilación endovesical de BCG
}

Antoni Vicens Vicens, Fernando García Montes, Marta de la Cruz Ruiz, Enrique Pieras Ayala, Mariano Ozonas Moragues

Servicio de Urología. Hospital Universitario Son Dureta. Palma de Mallorca.

P

aciente varón de 67 años de edad con anteceden-

tes de RTU por tumor vesical con informe anatomopatológico de pT1 G3 asociado a CIS. Tres días después de recibir la primera instilación intravesical con BCG inició un cuadro de fiebre con escalofríos, malestar general, sudoración profusa diaria y disnea progresiva hasta hacerse de reposo, por lo que acudió al área de urgencias de nuestro hospital. La exploración fisica objetivó fiebre con crepitantes bibasales. La gasometría arterial demostró insuficiencia respiratoria aguda. Se realizó Radiografia simple de tórax (Fig. la y b) que mostró un patrón intersticial bilateral de predominio basal. El paciente fue ingresado para iniciar tratamiento precoz con tuberculostáticos, corticoides y oxigenoterapia, desapareciendo la fiebre a las 24 horas del ingreso. Una vez estabilizado se practicaron Pruebas Funcionales Respiratorias que pusieron de manifiesto un patrón obstructivo de grado ligero, con alteración grave de la difusión de $\mathrm{CO}$ y se realizó un TAC toraco-abdominal (Fig. 2ay b) donde se constató la existencia de micronódulos pulmonares bilaterales distribuidos por todo el parénquima pulmonar; engrosamiento de los septos interlobulillares bilaterales; enfisema pulmonar paraseptal y centrolobular de predominio en lóbulos superiores. Estos hallazgos confirmaron el diagnóstico de sospecha al ingreso de neumonitis post-instilación intravesical de BCG. El paciente fue dado de alta a los 7 días del ingreso, sin fiebre y con correcta función respiratoria, para continuar tratamiento específico ambulatorio.
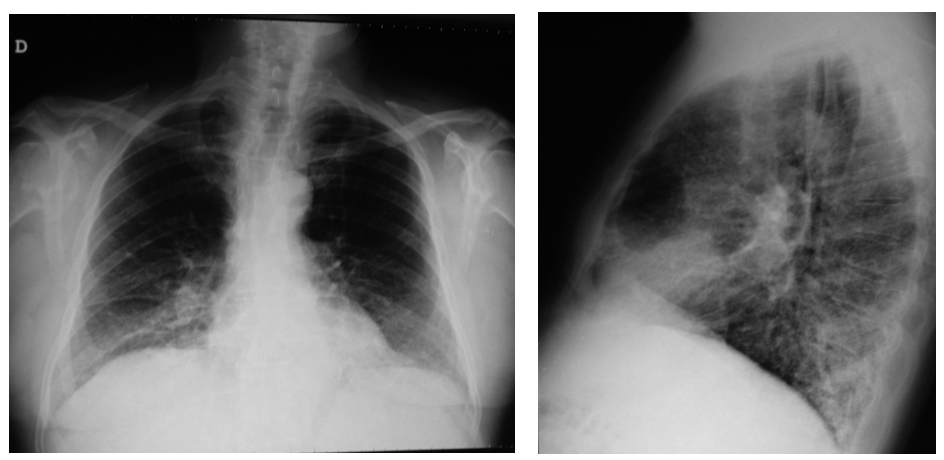

FIGURA 1
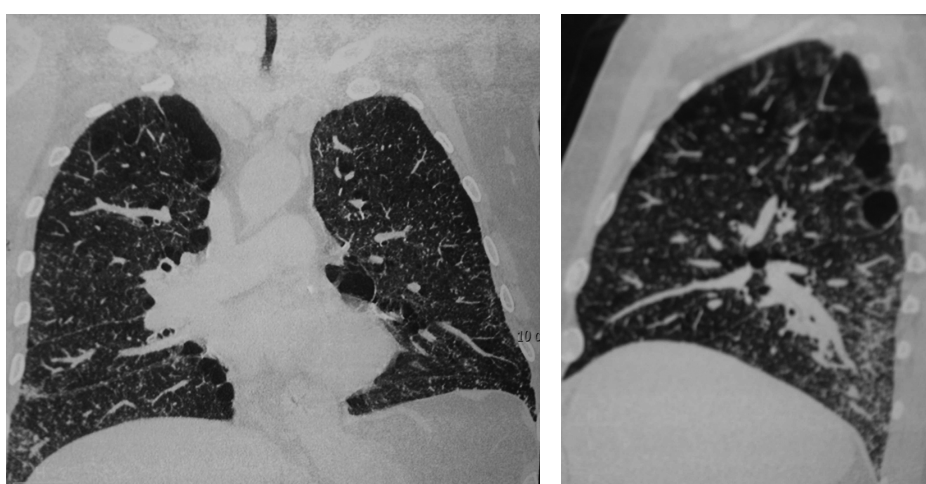

FIGURA 2

Correspondencia autor: Dr. Antoni Vicens Vicens

Servicio de Urología. Hospital Universitario Son Dureta

Andrea Doria, 55 - 07014 Palma de Mallorca

Tel.: 971175000

E-mail autor: docvic24@hotmail.com

Información artículo: Imágenes en Urología

Trabajo recibido: junio 2008

Trabajo aceptado: julio 2008 